\title{
Nutritional value and sensory acceptability of fish burger prepared with flaxseed flour
}

\author{
Muhsine DUMAN ${ }^{1 *}$ (D)
}

\begin{abstract}
Flaxseed flour has gained popularity among consumers worldwide due to the various nutrients and bioactive compounds it contains. The aim of this study was to evaluate the cooking yields, the nutritional value, and the sensory acceptability of fish burgers with an addition of flaxseed flour in different concentrations $(5,10$, and $15 \%)$. The results showed that the cooking yields $(79.2 \%)$ of the F0 (control) group was lower $(\mathrm{p}<0.05)$ than the burger to which flaxseed four was added. The flaxseed addition had some effect on the nutritional value of the fish burgers. The flaxseed rates increased the protein, but the fat content did not change significantly. The control group had the highest moisture and the lowest ash. Fish burgers made with the addition of $15 \%$ flaxseed flour had the highest energy value and the lowest moisture. There was no statistically significant difference among the fish burger groups with respect to sensory properties. The general acceptability scores showed that the group with the most positive response was the one containing $10 \%$ flaxseed flour fish burgers.
\end{abstract}

Keywords: fish burgers; flaxseed flour; acceptance.

Practical Application: Adding flaxseed flour in the formulation of fish burgers increases the nutritional value of the product without decreasing its sensory preference and also this study could be the basis for new studies.

\section{Introduction}

Luciobarbus esocinus (Heckel, 1843) is found throughout the Euphrates and Tigris rivers Turkey. İt is one of the biggest freshwater fish in Turkey. Its weight can be over $100 \mathrm{~kg}$ and It is relatively delicious and its economic value is high (Geldiay \& Balik, 2007).

Flaxseed (Linum usitatissimum) has been part of human nutrition for years. Recent research studies have shown that flaxseed is an important plant source containing beneficial compounds for health besides being rich in alpha-linolenic acid (ALA), good quality protein, fat, antioxidant, lignins and fiber (Goyal et al., 2014). According to Gutierrez et al. (2010), the chemical composition of the flaxseed carried out a high content of oil (43.90\%) and protein $(21.34 \%)$. The popularity of flaxseed has grown rapidly in recent years not only for their nutritional properties but also beneficial effect on the growth and development of children as well as on reducing the risk of cardiovascular disease, diabetes, gastro-intestinal health and brain development and function (Parikh et al., 2019). Many reports have focussed on alternative products from flaxseed as a functional food source such as bakery products, trorilla and cakes (Alpaslan \& Hayta, 2006; Rendón-Villalobos et al., 2009; Moraes et al., 2010). However, there are almost no studies on fish burger produced from fish mince.

Fish is a food of excellent providing high quality protein rich in essential amino acids, omega- 3 fatty acids and a wide variety of vitamins and minerals. In recent years, it has focused on healthier fish and meat products by reducing what are widely perceived as negative constituents and/or adding ingredients that are beneficial to human health (Vidal et al., 2019; Cilli et al., 2020;
Paglarini et al., 2020; Vidal et al., 2020a; Vidal et al., 2020b; Shekarabi, et al., 2020). Besides, consumers' preference for ready-to-eat foods, including fish and products has also increased. Among this food, fish products are very popular. Fish burgers are considered ready-made seafood products and are made from various kinds of fish (Yerlikaya et. al., 2004). However, there are almost no studies on fish products produced from flaxseed as a functional component. The purpose of this research was to prepare fish burgers with different concentrations $(5,10$ and $15 \%)$ of flaxseed, to characterize their nutritional value and to evaluate sensory acceptability.

\section{Material and methods}

\subsection{Preparation of fish burger}

Luciobarbus esocinus (average weight and length, $1247.2 \pm 181.2 \mathrm{~g}$ and $50.5 \pm 1.61 \mathrm{~cm}$, respectively) used in this study were purchased at local markets in Elazığ, Turkey, and the samples were transferred to the laboratory in ice within an hour. They were weighed and then remove the head and viscera and washed. Then, they were filleted and deboned manually. Mincing of fillets was performed by a domestic food processor (Arçelik, Robomaster, Turkey). The mince obtained from L. esocinus muscle was used to prepare fish burgers. Flaxseed flour and other ingredients were purchased from local markets in Elazığ.

The minced meat was divided into four groups. F0, control group, without added flaxseed flour and F5, F10, F15, treated 
samples with flaxseed flour 5, 10 and $15 \%(\mathrm{w} / \mathrm{w})$. Ingredients were added to each group according to the following formulation: $5 \%$ onion, $1.5 \%$ salt, $0.5 \%$ red pepper, $0.02 \%$ black pepper and $0.02 \%$ cumin. The ingredients were homogenized with a kitchen blender, refrigerated at $4{ }^{\circ} \mathrm{C}$ for $1 \mathrm{~h}$. Fish burger was prepared by hand $(31.42 \pm 3.43)$ and cooked in an electric oven at $175^{\circ} \mathrm{C}$ for $20 \mathrm{~min}$ and after cooling, the fish burger was packaged in Nylon/ polyethylene bags for different analyses.

\subsection{Percent cook product yield}

The cooking yields of the burger (\%) were determined by measuring the weight of the fish burgers before and after cooking, as described by Nisar et al. (2009) for ten replicates per treatment and were calculated as the ratio of cooked weight to uncooked weight, expressed as a percentage.

Cooking Yield $(\%)=\frac{\text { Cooked fish burger weight }}{\text { Uncooked fish burger weight }} \times 100$

The moisture retention (\%) was determined according to the equation below: (El-Magoli et al., 1996).

Moisture retention $(\%)=\frac{\% \text { yield } \mathrm{X} \% \text { moisture in cooked burger }}{100}$

\subsection{Proximate analysis, energy value and $\mathrm{pH}$}

The determination of moisture, protein, fat, and ash contents of fresh fish and fish burgers determined according to the standard method of Association of Official Analytical Chemists (2000). Total carbohydrate was calculated by numerical formula (carbohydrate $=100-$ moisture + protein + fat + ash $)$. The total calories value (Kcal) of cooked fish burgers was determined using the below equation

Energy $(\mathrm{kcal})=4 \times($ g proteins $+\mathrm{g}$ carbohydrate $)+9 \times(\mathrm{g}$ fat $)$.

The $\mathrm{pH}$ was measured using a digital $\mathrm{pH}$ meter (Thermo Scientific Orion 3-Star pH Benchtop, USA) with a calibrated electrode, which was inserted directly into fish burger for reading.

\subsection{Sensory analysis}

Sensory acceptability of fish burger samples were carried out by a ten member ( 5 females, 5 males) panel. Fish burger samples were assessed on the basis of appearance, ordour, flavour, texture and general acceptability. Preference scores were used a nine point hedonic scale $(9=$ like extremely, $5=$ neither like nor dislike and $1=$ dislike extremely) (Lawless \& Heymann, 1998).

\subsection{Statistical analysis}

Data are studied as the mean and standard deviation in triplicates. Differences between groups were analyzed by using the statistical software package SPSS for Windows SPSS Version 22.0 for one-way analysis of variance. Duncan multiple comparison tests was used to compare the differences among the variable groups. The Statistical significance level was considered to be $\mathrm{p}<0.05$.

\section{Results and discussion}

\subsection{Cooking yield, moisture retention}

Cooking yield of the control group and flaxseed fish burgers are shown in Figure 1. The cooking yields were 79.2, 81.24, 81.88 and $83.42 \%$, for flaxseed flour additions of 0 (control; F0), 5 (F5), 10 (F10) and 15 (F15)\%, respectively. Cooking yield was significantly increased significantly with the increasing levels of flaxseed flour $(\mathrm{p}<0.05)$ (Figure 1). This increase could be due to the increase in dry matter with the added flaxseed flour. Cooking yields of fish burgers varied between $79.2 \%$ and $83.42 \%$. Flaxseed fish burger had a somewhat higher cooking yield than the control F0 (control) fish burger. The highest cooking yields (83.42) was found in fish burger in F15 samples $(\mathrm{p}<0.05)$. In the control samples, lower cooking yield could be associated with the excessive loss of water during cooking. Reddy et al. (2018) reported of the cooking yield higher with treatment groups compared to the control group. However, Ali et al. (2019) reported that control fish burger (87.51\%) had higher cooking yield values than fish burgers formulated with various rates of mashed pumpkin pulp or mashed potato.

Moisture retention of the fish burger is given in Figure 2. Moisture retention of fish burger was determined as 57.92\%

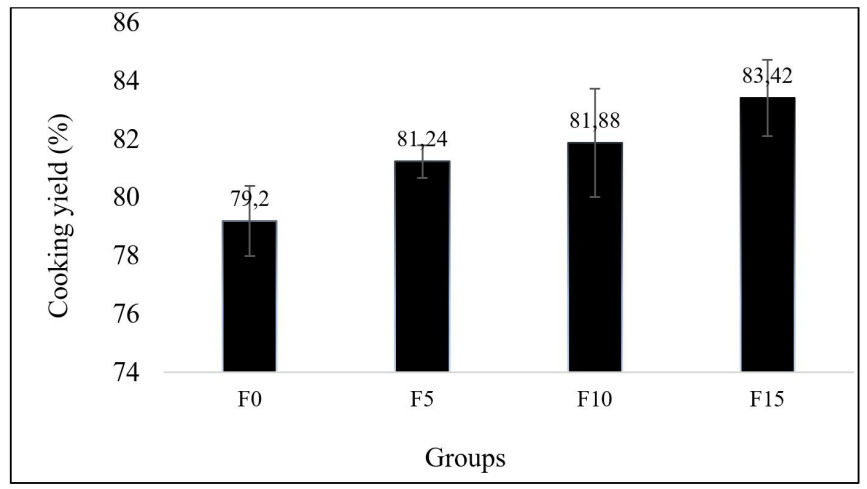

Figure 1. Yield of burgers incorporated with different percentages of flaxseed. F0: Fish burger formulated without flaxseed flour; F5: fish burger formulated with 5\%flaxseed flour; F10: fish burger formulated with $10 \%$ flaxseed flour; F15: fish burger formulated with 15\% flaxseed flour.

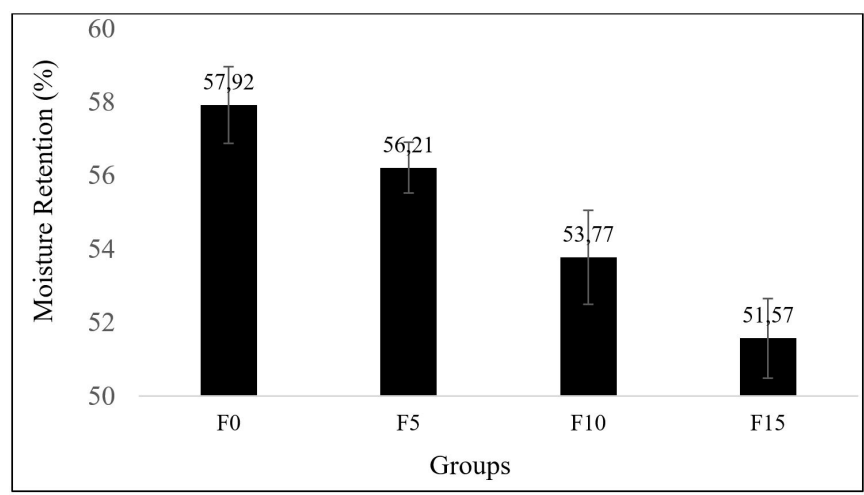

Figure 2. Moisture retention of fish burger incorporated with different percentages of flaxseed. F0: Fish burger formulated withoutflaxseed flour; F5: fish burger formulated with 5\%flaxseed flour; F10: fish burger formulated with $10 \%$ flaxseed flour; F15: fish burger formulated with $15 \%$ flaxseed flour. 
F0, 56.21\% F5, 53.77\% F10, and 51.57\% F15. The moisture retention of the fish burgers by adding flaxseed flour was less than the control $(p<0.05)$. These differences could be due to the differences in moisture content for all types of burgers. The highest moisture retention was found in the control groups (57.92\%). Similarly, Serdaroğlu et al. (2018) found that beef patties formulated with dried pumpkin pulp and seed mixture showed lower moisture retention than control groups.

\subsection{Proximate composition, energy value and $\mathrm{pH}$}

The proximate composition of raw fish was determined as $78.26 \%$ moisture, $18.12 \%$ protein $3.2 \%$ lipid, and $0.89 \%$ ash. Similarly, the proximate composition was reported by Kuzgun (2017). Proximate compositions, energy value, and $\mathrm{pH}$ of the burger formulation with different flaxseed flours levels are given in Table 1. For the cooked burgers in the present study, the protein and lipid contents of all treatments were almost the same $(p>0.05)$. However, the incorporation of different flaxseed flour levels affected the moisture and ash content of the cooked burgers. The moisture content of burgers decreased with different flaxseed flour levels incorporated when compared to the control, and each was significantly $(\mathrm{p}<0.05)$ different. The flaxseed addition reduced the moisture of the fish burger. The F5 and F10 groups had a higher moisture content compared to the F15 groups $(\mathrm{p}<0.05)$. Similar findings were reported by Bilek \& Turhan (2009).

The ash content was similar in the F0, F5, and F10 samples although the F15 samples had higher ash content compared to the F5 and F10 groups $(\mathrm{p}<0.05)$, probably due to the high mineral content of flaxseed flour. Bilek \&Turhan (2009) reported that the ash content increased with the addition of the flaxseed flour in beef patties. Flaxseed flour contains $20.3 \%$ protein and $37.1 \%$ lipid contents and a high level of a-linolenic fatty acid (Kajla et al., 2014). The carbohydrate content of the fish burgers formulated with flaxseed flour were higher $(p<0.05)$ than the control fish burger; this could be attributed to the carbohydrate content of the flaxseed flour. Bilek \& Turhan (2009) found that beef patties formulated with flaxseed flour showed a higher carbohydrate content than control groups. The carbohydrate contents of fish burgers increased by the addition of different levels of flaxseed flour $(\mathrm{p}<0.05)$. The carbohydrate content of fish burgers ranged from 0.39 to 6.64 (Table 1 ).

The usable energy content of burgers ranged from $107.00 \pm 5.47$ to $451.67 \pm 4.99 \mathrm{Kcal} / 100 \mathrm{~g}$. The amount of energy value in the flaxseed-added burger increased between 25\% and 53\% approximately (Table 1 ). The amount of energy value in the flaxseed-added burger was 107.0, 133.22, 147.93, and 163.77 for F0, F5, F10, and F15, respectively. There were significant statistical differences $(\mathrm{p}<0.05)$ between the samples. Studies show that the added flaxseed caused an increase in the energy value (Bilek \& Turhan, 2009; Novello \& Pollonio, 2013).

The $\mathrm{pH}$ values of fish burgers ranged from 5.93 to 6.10 (Table 1). The $\mathrm{pH}$ values of formulas treated with flaxseed flour ( $p>0.05$ ) non- significant increase in comparison with that of control groups. Bilek \& Turhan (2009) reported not significantly different among treatments $\mathrm{pH}$ of beef patties made with flaxseed flour at different concentrations.

\subsection{Sensory evaluation}

The addition of non-meat ingredients to fish product formulations could cause significant changes in the sensory properties of the product. Therefore, the sensory properties of the product should be evaluated and it is important to make necessary regulations to the content. The sensory evaluations of fish burgers are shown in Table 2.

The results show that there were no statistically significant differences $(p>0.05)$ between all samples in odour, texture and general acceptability. The odour, texture and general acceptability scores range from 8.2-8.5; 7.3-7.7 and from $7.9-8.3$, respectively. These scores denote good acceptability (score of) on a 9-point hedonic scale. The appearance scores of control group samples were significantly $(\mathrm{p}<0.05)$ different from each other except for F5. The panelists more preferred the appearance of burger with $10 \%$ of flaxseed flour added than the others. The lowest score value of appearance was recorded for F0 (7.4). The flavour score at F10 (8.5) was preferred by the panelists than the other fish burger. The fish burger with F10 were significantly different $(\mathrm{p}<0.05)$ to F15 (7.0) groups. Flavour showed the burger made from $10 \%$ of flaxseed flour is the most preferable by consumers tested. On the contrary,

Table 1. Proximate composition, energy value and $\mathrm{pH}$ of fish burgers incorporated with different percentages of flaxseed.

\begin{tabular}{|c|c|c|c|c|}
\hline \multirow{2}{*}{ Characteristics } & \multicolumn{4}{|c|}{ Formulations } \\
\hline & F0 & F5 & F10 & F15 \\
\hline Moisture (\%) & $73.13 \pm 0.88^{\mathrm{a}}$ & $69.19 \pm 0.81^{\mathrm{b}}$ & $65.67 \pm 1.25^{c}$ & $61.82 \pm 0.86^{\mathrm{d}}$ \\
\hline Protein (\%) & $20.34 \pm 1.05$ & $21.01 \pm 1.14$ & $22.80 \pm 1.63$ & $23.03 \pm 1.09$ \\
\hline Lipids (\%) & $3.77 \pm 0.33$ & $3.92 \pm 0.45$ & $4.55 \pm 0.48$ & $5.09 \pm 0.35$ \\
\hline Ash (\%) & $2.37 \pm 0.27^{\mathrm{a}}$ & $2.62 \pm 0.44^{\mathrm{a}}$ & $3.04 \pm 0.24^{\mathrm{ab}}$ & $3.60 \pm 0.28^{\mathrm{b}}$ \\
\hline Carbohydrate & $0.39 \pm 0.2^{\mathrm{a}}$ & $3.26 \pm 0.28^{\mathrm{b}}$ & $3.94 \pm 0.46^{\mathrm{b}}$ & $6.46 \pm 0.98^{c}$ \\
\hline Energy, kcal/100 g & $107.0 \pm 5.47^{\mathrm{a}}$ & $133.22 \pm 4.81^{\mathrm{b}}$ & $147.93 \pm 8.96^{c}$ & $163.77 \pm 4.99^{\mathrm{d}}$ \\
\hline $\mathrm{pH}$ & $5.93 \pm 0,02$ & $5.97 \pm 0,04$ & $6.09 \pm 0,01$ & $6.10 \pm 0,00$ \\
\hline
\end{tabular}

F0: Fish burger formulated without flaxseed flour; F5: fish burger formulated with 5\%flaxseed flour; F10: fish burger formulated with 10\% flaxseed flour; F15: fish burger formulated with $15 \%$ flaxseed flour. a,b,c Values in the same row with different superscript letters are significantly different $(\mathrm{p}<0.05)$ 
Table 2. Sensory analysis results of fish burger incorporated with different percentages of flaxseed.

\begin{tabular}{lcccc}
\hline & \multicolumn{3}{c}{ Formulations } \\
\cline { 2 - 5 } & Fo & F5 & F10 & F15 \\
\hline Appearance & $7.4 \pm 1.17^{\mathrm{a}}$ & $8.0 \pm 0.82^{\mathrm{ab}}$ & $8.5 \pm 0.53^{\mathrm{b}}$ & $8.4 \pm 0.70^{\mathrm{b}}$ \\
Odour & $8.3 \pm 0.48$ & $8.3 \pm 0.43$ & $8.5 \pm 0.97$ & $8.2 \pm 0.92$ \\
Flavour & $8.0 \pm 0.82^{\mathrm{ab}}$ & $8.0 \pm 0.47^{\mathrm{ab}}$ & $8.5 \pm 0.97^{\mathrm{b}}$ & $7.0 \pm 1.45^{\mathrm{a}}$ \\
Texture & $7.3 \pm 1.25$ & $7.4 \pm 1.07$ & $7.5 \pm 1.08$ & $7.7 \pm 1.34$ \\
General acceptability & $7.9 \pm 0.56$ & $8.0 \pm 0.47$ & $8.3 \pm 0.67$ & $8.2 \pm 0.79$ \\
\hline
\end{tabular}

F0: Fish burger formulated without flaxseed flour; F5: fish burger formulated with 5\%flaxseed flour; F10: fish burger formulated with 10\% flaxseed flour; F15: fish burger formulated with $15 \%$ flaxseed flour. ${ }^{a, b}$ Values in the same row with different superscript letters are significantly different $(\mathrm{p}<0.05)$.

Bilek \& Turhan (2009) found that the sensory scores of beef patties increased as the flaxseed content decreased.

\section{Conclusions}

Flaxseed is a valuable nutrient additive because of its various biologically active compounds. The results showed that the incorporation of flaxseed flour in fish burgers was promising with evidence of a significant increase in the fat and ash content. The analysis indicated that the addition of flaxseed flour reduced the cooking loss of the burger while increasing its energy value. The flavour scores of the samples decreased with the $15 \%$ flaxseed addition.

\section{References}

Ali, H. A., Mansour, E. H., \& Bedawey, E.-I. (2019). Evaluation of tilapia fish burgers as affected by different replacement levels of mashed pumpkin or mashed potato. Journal of the Saudi Society of Agricultural Sciences, 18(2), 127-132. http://dx.doi.org/10.1016/j. jssas.2017.01.003.

Alpaslan, M., \& Hayta, M. (2006). The effects of flaxseed, soy and corn flours on the textural and sensory properties of a bakery product. Journal of Food Quality, 29(6), 617-627. http://dx.doi. org/10.1111/j.1745-4557.2006.00099.x.

Association of Official Analytical Chemists - AOAC. (2000). Official methods of Analysis of the Association of Official Analytical Chemists (17th ed.). Washington DC: AOAC.

Bilek, A.E., \& Turhan, S. (2009). Enhancement of the nutritional status of beef patties by adding flaxseed flour. Meat Science, 82(4), 472-477. http://dx.doi.org/10.1016/j.meatsci.2009.03.002. PMid:20416676.

Cilli, L. P., Contini, L. R. F., Sinnecker, P., Lopes, P. S., Andreo, M. A., Neiva, C. R. P., Nascimento, M. S., Yoshida, C. M. P., \& Venturini, A. C. (2020). Effects of grape pomace flour on quality parameters of salmon burger. Journal of Food Processing and Preservation, 44(2), 1-11. http://dx.doi.org/10.1111/jfpp.14329.

El-Magoli, S. B., Laroia, S., \& Hansen, P. M. (1996). Flavor and texture characteristics of low fat ground beef patties formulated with whey protein concentrate. Meat Science, 42(2), 179-193. http://dx.doi. org/10.1016/0309-1740(95)00032-1. PMid:22060683.

Geldiay, R., \& Balik, S. (2007). Turkiye Tatlisu Balıkları. Bornova, Izmir: Ege Universitesi Basım Evi.

Goyal, A., Sharma, V., Upadhyay, N., Gill, S., \& Sihag, M. (2014). Flax andflaxseed oil: Anancient medicine \& modern functional food. Journal of Food Science and Technology, 51(9), 1633-1653. http:// dx.doi.org/10.1007/s13197-013-1247-9. PMid:25190822.
Gutierrez, C., Rubilar, M., Jara, C., Verdugo, M., Sineiro, J., \& Shene, C. (2010). Flaxseed and flaxseed cake as a source of compounds for food industry. Journal of Soil Science and Plant Nutrition, 10(4), 454-463. http://dx.doi.org/10.4067/S0718-95162010000200006.

Kajla, P., Sharma, A., \& Sood, D. R. (2014). Flaxseed-a potential functional food source. Journal of Food Science and Technology, 52(4), 1857-1871. http://dx.doi.org/10.1007/s13197-014-1293-y. PMid:25829567.

Kuzgun, N.K. (2017). Luciobarbus esocinus, (Heckel 1843)'den Elde edilen balık cipslerinin besin kompozisyonu ve duyusal özelliklerinin belirlenmesi. Süleyman Demirel Üniversitesi Eğirdir Su Ürünleri Fakültesi Dergisi, 13(2), 153-162. http://dx.doi.org/10.22392/egirdir.283013.

Lawless, H., \& Heymann, H. (1998). Sensory evaluation of food: principles and practices (2nd ed). NewYork: Champan \& Hall.

Moraes, E. A., Dantas, M. I. S., Morais, D. C., Silva, C. O., Castro, F. A. F., Martino, H. S. D., \& Ribeiro, S. M. R. (2010). Sensory evaluation and nutritional value of cakes prepared with whole flaxseed flour. Food Science and Technology (Campinas), 30(4), 974-979. http:// dx.doi.org/10.1590/S0101-20612010000400021.

Nisar, P. U. M., Chatli, M. K., \& Sharma, D. K. (2009). Efficacy of tapioca starch as a fatreplacer in low-fat buffalo meat patties. Buffalo Bulletin, 28(1), 18-22.

Novello, D., \& Pollonio, M. A. R. (2013). Golden flaxseed and its byproducts in beef patties: physicochemical evaluation and fatty acid profile. Ciência Rural, 43(9), 1707-1714. http://dx.doi.org/10.1590/ S0103-84782013000900027.

Paglarini, C. S., Vidal, V. A. S., Santos, M., Coimbra, L. O., Esmerino, E. A., Cruz, A. G., \& Pollonio, M. A. R. (2020). Using dynamic sensory techniques to determine drivers of liking in sodium and fatreduced Bologna sausage containing functional emulsion gels. Food Research International, 132, 109066. http://dx.doi.org/10.1016/j. foodres.2020.109066. PMid:32331676.

Parikh, M., Maddaford, T. G., Austria, J. A., Aliani, M., Netticadan, T., \& Pierce, G. N. (2019). Dietary flaxeed as a strategy for improving human health. Nutrients, 11(5), 1171. http://dx.doi.org/10.3390/ nu11051171. PMid:31130604.

Reddy, G. V., Reddy, B. O., Indumathi, J., \& Ravi, A. (2018). Quality characteristics of functional chicken meat nuggets extended with flax seed flour. Indian Journal of Poultry Science, 53(2), 219-224. http://dx.doi.org/10.5958/0974-8180.2018.00042.9.

Rendón-Villalobos, R., Agama-Acevedo, E., Osorio-Diaz, P., Tovar, J., \& Bello-Pérez, L. A. (2009). Proximal composition and in vitro starch digestibility in flaxseed added corn tortilla. Journal of the Science of Food and Agriculture, 89(3), 537-541. http://dx.doi. org/10.1002/jsfa.3490. 
Serdaroğlu, M., Kavusan, H. S., Ipek, G., \& Ozturk, B. (2018). Evaluation of the quality of beef patties formulated with dried pumpkin pulp and seed. Han-gug Chugsan Sigpum Hag-hoeji, 38(1), 1-13. http:// dx.doi.org/10.5851/kosfa.2018.38.1.001. PMid:29725220.

Shekarabi, S. P. H., Monjezi, M. A., Shaviklo, A. R., \& Mohamed, H. M. H. (2020). Physicochemical properties, electrophoretic patterns, and sensory attributes of fish burger incorporated with shrimp, camel, and ostrich meats. Journal of Aquatic Food Product Technology, 29(8). http://dx.doi.org/10.1080/10498850.2020.1818155.

Vidal, V. A. S., Biachi, J. P., Paglarini, C. S., Pinton, M. B., Campagnol, P. C. B., Esmerino, E. A., Cruz, A. G., Morgano, M. A., \& Pollonio, M. A. R. (2019). Reducing 50\% sodium chloride in healthier jerked beef: An efficient design to ensure suitable stability, technological and sensory properties. Meat Science, 152, 49-57. http://dx.doi. org/10.1016/j.meatsci.2019.02.005. PMid:30802818.
Vidal, V. A. S., Paglarini, C. S., Freitas, M. Q., Coimbra, L. O., Esmerino, E. A., Pollonio, M. A. R., \& Cruz, A. G. (2020a). Q Methodology: An interesting strategy for concept profile and sensory description of low sodium salted meat. Meat Science, 161, 108000. http://dx.doi. org/10.1016/j.meatsci.2019.108000. PMid:31707157.

Vidal, V. A. S., Santana, J. B., Paglarini, C. S., da Silva, M. A. A. P., Freitas, M. Q., Esmerino, E. A., Cruz, A. G., \& Pollonio, M. A. R. (2020b). Adding lysine and yeast extract improves sensory properties of low sodium salted meat. Meat Science, 159, 107911. http://dx.doi.org/10.1016/j.meatsci.2019.107911. PMid:31474317.

Yerlikaya, P., Gokoglu, N., \& Uran, H. (2004). Quality changes of fish patties producedfrom anchovy during refrigerated storage. European Food Research and Technology, 220(3), 287-291. http:// dx.doi.org/10.1007/s00217-004-1035-x. 